\section{A NEW SPECIES OF BUTTERFLY FOR SASKATCHEWAN}

by Ronald R. Hooper, Regina

While warking on insects in the Saskatchewan Museum of Natural History I noticed in the J. B. Wallis collection of lepidoptera a specimen of what appeared to be the Acmon Blue from Roche Percee, Saskatchewan.

I sent the specimen to Mr. C. F. Dos Passos of Mendham, New Jersey, and have recently had it returned with the confirmation that it is a female Acmon Blue (Plebeius acmon acmon West \& Hew.).

I remember conversing with the late Mr. J. B. Wallis of Winnipeg in 1954 and asking him about the possibility of finding the Acmon Blue in Saskatchewan. He assured me that it wasn't found in the province; however, there was a Saskatchewan specimen hiding in his collection of which he was apparently not aware. Now, Mr. Wallis was a well experienced entomologist, having named several species of insects, so I am wondering if perhaps the specimen was only papered at the time and that he hadn't noticed what it was because it wasn't mounted.

The date on the specimen is the $7 \mathrm{th}$ of July but the year is not given. Cther butterflies in his collection that are from Roche Percee were taken on August 24, 1953.

The Acmon Blue ranges from the Rocky Mountains and foothills of southern Alberta across Montana to western North Dakota and rarely to Minnesota. It is not on the Manitoba list of butterflies.

This species is one of our most nicely marked species of "Blues". It is recognized by the broad, orange submarginal band on the hind wings above. The female Melissa Blue (Lycaeides melissa Edw.) has this also but she has orange sub-marginal bands on the forewings above also. The female Shasta Blue (Plebeius shasta Edw.) has an orange submarginal band on the hind wings above, but it is a much narrower band than that of the Acmon Blue.

This makes 12 species of "Blues" that have been recorded from Saskatchewan. Only eight of these are on the Manitoba list, but all 12 are on the Alberta list.

Probably the next closest species of "Blue" to Saskatchewan is the Colorado Blue (Philotes battoides) recorded from the west side of the Great Divide at Missoula, Montana.

\section{YELLOW GOAT'S-BEARD, AN AGGRESSIVE INVADER}

\author{
by Keith F. Best, Swift Current
}

In our series of plants ranging from those of extremely dry habitats to the aquatic vegetation, we have spent considerable time on the flora found on the dry prairie. The species illustrated here is one of these, belonging to the Compositae or Composite Family.

Yellow goat's-beard (Tragopogon dubius Scop.), is a biennial weed that has been introduced from Europe and, having found conditions to its liking, has rapidly spread across the prairies on roadsides and waste places. Arising from a deep fleshy taproot, the plant grows to a height of one to two feet. The stems are hollow and contain a milky sap. The flower heads are sulphur-yellow and are about an inch and a half across, with 10 to 14 green bracts that are longer than the florets. The clasping leaves are narrow and grass-like. The heads are single on a long stem, which is swollen just below the head. When in fruit, the plant is most conspicuous, with beautiful white spherical seed-heads some three or four inches in diameter, that resemble a giant dandelion. The individual seeds which are about one-half inch long, are ribbed and taper to a long beak, and bear a parachute of white hairs.

Most of the seedlings will have emerged by mid-May, and flowering is general by early June, or "wild strawberry time" as it is called in Lloyd Carmichael's book Prairie Wildflowers. 


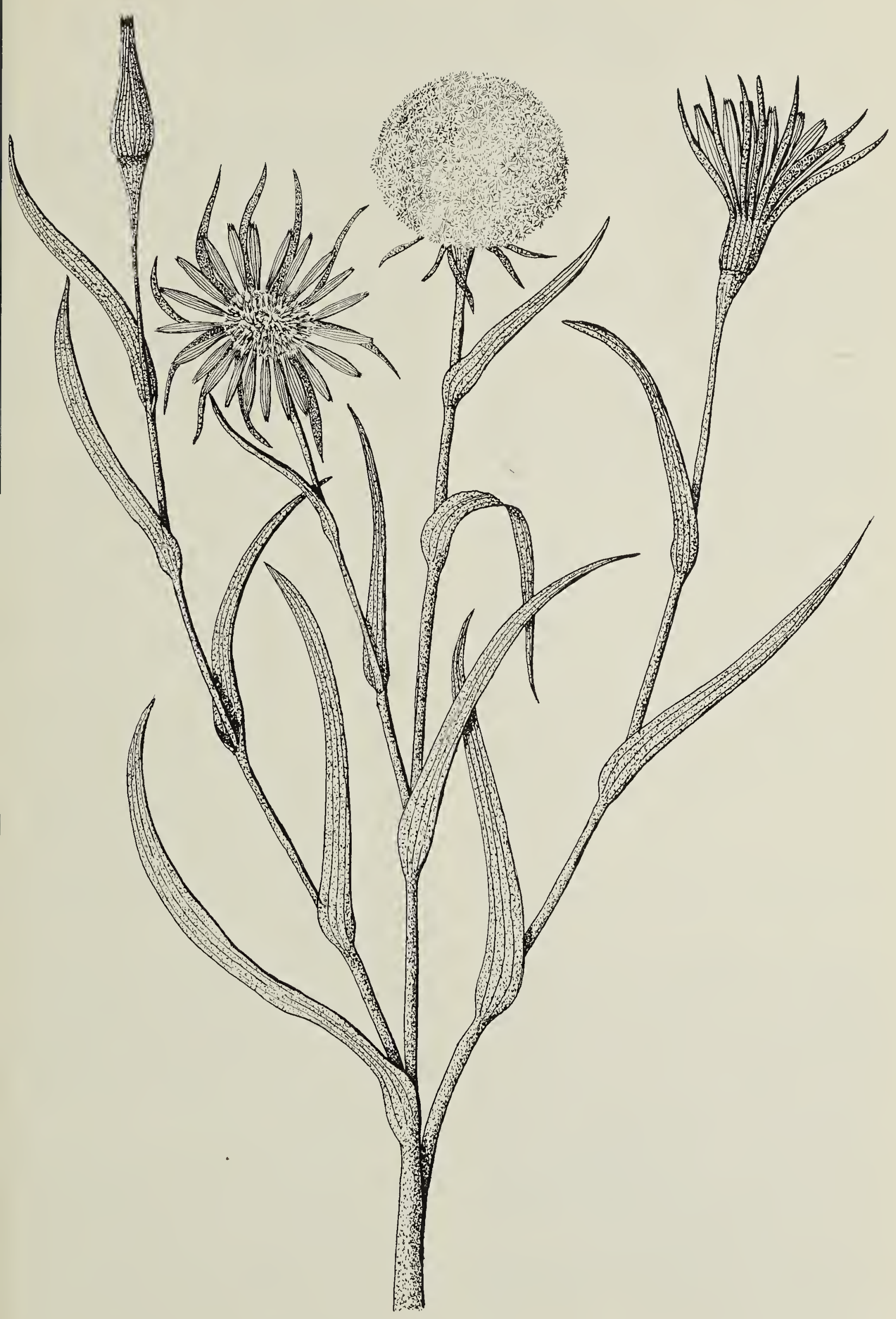

